\title{
Encountering the Evidence: Co-operatives and Poverty Reduction in Africa
}

\section{Fredrick O Wanyama, Patrick Develtere and Ignace Pollet}

\begin{abstract}
Discussion on the contribution of co-operatives to poverty reduction in Africa since the early 1990s has quite often been based on their potential role rather than the actual impact partly due to the dearth of empirical studies. This paper departs from such discussions to empirically demonstrate that co-operatives have significantly contributed to poverty reduction in Africa by, among others, mobilising and distributing financial capital; creating employment and income-generating opportunities; availing a forum for education and training; and creating solidarity schemes that cater for unexpected expenses related to illness, social welfare, death and other socio-economic problems.
\end{abstract}

\section{Introduction}

The growing concern with poverty reduction in developing countries has triggered an emerging consensus among many actors, including the United Nations (UN), the International Labour Organisation (ILO), the International Cooperative Alliance (ICA) and the European Union $(\mathrm{EU})$, that the co-operative enterprise is the only form of organisation that meets all dimensions of poverty alleviation. The broad argument is that co-operatives have the advantages of identifying economic opportunities for the poor; empowering the disadvantaged to defend their interests; and providing security to the poor by allowing them to convert individual risks into collective risks. Consequently, co-operatives are increasingly being presented as a pre-condition for a successful drive against poverty and exclusion, more so in Africa (Birchall, 2004; 2003; ILO/ICA, 2003).

Nevertheless, the arguments on the suitability of co-operatives for poverty alleviation in Africa tend to be based on expectations rather than the empirical functioning of these organisations. This is particularly the case because there has been a dearth of up-to-date literature that conveys the status of African co-operatives since the liberalisation of the sector in the mid 1990s. The last comprehensive studies of co-operatives in the early 1990s argued that these organisations had virtually failed to live up to this expectation (Birchall, 2004: 3). The 1993 World Bank studies (Hussi, et al, 1993; Porvali, 1993), for example, acknowledged the potential role that co-operatives could play in the development process in Africa, but only if they were disentangled from the state, restructured and run on business principles in line with the then emerging market economy. Since then, there has been limited, if any, literature on how African co-operatives have fared in their contribution to poverty alleviation.

The purpose of this paper is to move the debate on the contribution of co-operatives to poverty reduction in Africa from "their potential role" (Birchall, 2003) to their actual impact, using empirical evidence from the field. It is based on data that were collected from eleven African countries in 2005 under the Essential Research for a Cooperative Facility for Africa study, which was initiated by the Co-operative Branch of the ILO; funded by the UK Department for International Development (DfID); and coordinated by the Higher Institute for Labour Studies (HIVA) at the Katholieke University of Leuven, Belgium ${ }^{1}$. From a rural livelihoods perspective, the paper illustrates that cooperatives in Africa have certainly contributed to poverty reduction by mediating members' access to assets and reducing exclusion by integrating the poor and the relatively well-off in the same income-generating opportunities. Nevertheless, hard data that can allow us to assess the exact proportion of the contribution of African co-operatives to poverty alleviation are still limited. What the paper does, therefore, is to give empirical indicators from eleven countries on the contribution of co-operatives in this regard.

\section{Co-operatives and Poverty in a Livelihood Framework}

Whereas poverty is a multi-faceted phenomenon that hinders the satisfaction of basic life requirements, the tendency has been for some analysts to conceptualise it in narrow economic terms by insinuating that it is simply the lack of money (Smith \& Ross, 2006: 6). We go beyond such conceptualisations to define it as a condition that deprives the individual the 
basic necessities for existence like food, water, shelter and clothing as well as other fundamentals to life like health, education, security, opportunity and freedom (Spence, 2005: 351-52). Deprivation of these basic and fundamental needs of life results into the exclusion of the individual in society (Sen, 1999).

Livelihood analysts (cf. Chambers and Conway, 1992; Carswell, 1997; Scoones, 1998; Davies and Hossain, 1997; Hussein and Nelson, 1998) have expressed the same idea in their definition of a livelihood as "... the assets (natural, physical, human, financial and social capital), the activities, and the access to these (mediated by organisations, institutions and social relations) that together determine the living gained by the individual or household" (Ellis, 2000: 10). Briefly, natural capital refers to natural resources like land, water, minerals, animals and trees that yield products to support human life. Physical capital includes the assets that result from economic production processes, such as tools, machines, buildings and land improvements. Human capital refers to the educational and health status of individuals, while social capital refers to the interactive networks and associations in which people participate to derive support towards earning a living. Finally, financial capital includes the stocks of cash and credit for purchasing either production or consumption goods (Ellis, 2000:8). So that poverty manifests not only in the lack of access to financial capital, but also deprivation of physical, natural, human and social capital.

This livelihood framework clearly shows that people's access to the assets that they require to earn a living is mediated by organisations. The utility of this framework is that it gives us an insight into the contribution of co-operatives as mediating agencies rather than mechanisms of political instrumentalisation - to poverty reduction in Africa.

Though co-operatives have attracted different definitions over time (ILO, 1960: 5), it is increasingly being accepted that a co-operative is:

An autonomous association of persons united voluntarily to meet their common economic, social and cultural needs and aspirations through a jointly owned and democraticallycontrolled enterprise. (ICA, 1995)

This definition, which is also contained in ILO Recommendation 193 of 2002 (ILO, 2002), suggests that co-operatives are, first and foremost, voluntary business associations formed by people of limited means ${ }^{2}$ through contribution of share capital that forms the basis of either sharing out the profits that may accrue from the business or the other use to which such profits may be put as determined by members. The latter partly explains why the management of a co-operative has to be democratic: to give the members the opportunity to determine how the proceeds of the enterprise can be utilised. Of course the other explanation for this form of management is that the association is open and voluntary: a member is free to join and also cease to be a member at his/her discretion.

Co-operatives take different structural forms in Africa. In Anglophone countries, co-operatives are broadly organised at two levels: the primary level and the secondary level. At the primary level are co-operative societies with individual persons as members, while co-operative unions are formed at the secondary level with co-operative societies as the members. Thus, in the latter case, co-operative societies in the same sector within a specific geographical region could join together to form a co-operative union for purposes of mobilising capital to invest in a bigger business venture that is beyond the reach of a single society. The same logic is used by co-operative unions to form co-operative federations and ultimately an apex organisation at the national level to represent all co-operatives in the country. Francophone and Lusophone countries, however, have a more loose structural organisation that recognise mutual societies, self-help associations, foundations and trusts as part of the co-operative movement. In this tradition, it is the social and economic objectives shared by the parties involved in a co-operative venture that unify them (Develtere, 2008).

In addition to this general structure, the tendency is for co-operatives to be formed around economic sectors and/or activities. For example, there are agricultural co-operatives, savings and credit co-operatives (SACCOs), housing co-operatives, consumer co-operatives, among others. Even within a given sector, specific activities attract the formation of specialised co-operative organisations. For instance, agricultural cooperatives in Kenya are mainly established to market members' produce. Consequently most of them are organised around the processing and marketing of specific cash crops, like coffee, cotton, pyrethrum, rice and dairy produce (Wanyama, 2008). 
From a livelihood perspective, these different types of co-operatives mediate the access of their members to assets that they utilise to earn a living. For instance, while SACCOs facilitate their members' access to financial capital, agricultural co-operatives help farmers to get access to physical capital. Similarly, consumer co-operatives make it possible for their members and the society at large to get access to household supplies (Birchall, 2004: 3). Such services ultimately help members to improve on their living conditions, thereby pulling some of them out of poverty. Let us demonstrate how co-operatives in Africa have done this.

\section{Co-operatives and Poverty Reduction in Africa}

The size of the co-operative movement in Africa has been steadily growing over the years despite the various impediments like state control up to the mid 1990s; and the liberal economic environment since the early 1990s, for which they had not been adequately prepared. Table 1 below illustrates this growth by comparing data for 1992 and 2005 in four selected countries that were recently surveyed.

Field data from our study shows there are approximately 150,000 collective socioeconomic undertakings in the eleven sampled countries that are considered to be co-operative types of businesses. This figure could be even higher if the semi-co-operative organisations in the Anglophone countries were also counted. For instance, the hundreds of burial societies and pre-co-operatives in South Africa are not included in this database. Nevertheless, this figure could also be much less if we subtracted the dormant ones. Estimates from Kenya, for instance, indicate that as many as $35 \%$ of the registered co-operatives may be dormant. A recent count in Uganda revealed that only $47 \%$ of the registered societies could qualify as "active".

It is, however, indicative that there has been increased growth and presence of co-operatives in Africa over the last decade, largely due to the proliferation of SACCOs. Even in countries where the co-operative movement was on the verge of collapse due to other factors like civil conflict, such as Rwanda and Uganda, the growth of co-operatives seem to be picking up. For instance, whereas there were only 554 co-operatives in Uganda in 1995 (ICA, 1996: 15), data from the Uganda Co-operative Alliance indicates that this figure had grown to 7,476 in 2005 (Develtere and Pollet, 2008). Though still recovering from the impact of the 1994 genocide that disrupted many economic activities, Rwanda was estimated to have 33,631 co-operative-type of organisations in 2005, with most of them operating in the financial sector (Ibid).

The membership of these organisations has also not remained static as the little evidence in Table 1 above show. It is estimated that seven per cent of the African population reportedly belongs to a co-operative, with some countries like Egypt, Senegal, Ghana, Kenya and Rwanda reporting a higher penetration rate of over ten per cent. Members of co-operative societies cut across ethnic backgrounds, the rural-urban divide and sometimes professional categories. Whereas members of agricultural co-operatives are largely rural farmers who occasionally belong to the same ethnic group, the majority of the members of non-agricultural co-operatives live in urban areas where there are people from diverse ethnic backgrounds participating in the same co-operatives. The proliferation of SACCOs, particularly in the urban areas, has brought people from different professional and income categories into the same co-operative venture. High-ranking professionals employed in organisations, around which SACCOs are formed, find themselves in the same co-operative with their junior employees. Thus, it is the services rendered by co-operatives that form the basis for membership in most countries rather than ethnic, class and professional bases.

Table 1: Number of Co-operatives and Members in selected countries, 1992 \& 2005

\begin{tabular}{|l|c|c|c|c|}
\hline & \multicolumn{2}{|c|}{ Number of Active Co-ope ratives } & \multicolumn{2}{c|}{$\begin{array}{c}\text { Co-operative Members } \\
\text { (in millions) }\end{array}$} \\
\hline Country & $\mathbf{1 9 9 2}$ & $\mathbf{2 0 0 5}$ & $\mathbf{1 9 9 2}$ & $\mathbf{2 0 0 5}$ \\
\hline Ghana & 1,000 & 2,850 & $\mathrm{n} / \mathrm{a}$ & 2.4 \\
\hline Kenya & 4,000 & 7,000 & 2.5 & 3.3 \\
\hline Nigeria & 29,000 & 50,000 & 2.6 & 4.3 \\
\hline Senegal & 2,000 & 6,000 & $\mathrm{n} / \mathrm{a}$ & 3.0 \\
\hline
\end{tabular}

Source: Porvali (1993); Develtere et al (2008) 
Indeed, in some countries like Kenya, SACCOs are even being formed among the self-employed in the informal and agricultural sectors, which is a complete departure from the past where they were mainly formed among the salaried that could make their share contributions through a monthly payroll check-off system.

\section{Employment Creation and Income-generation}

Co-operatives create employment opportunities in three different ways. First, they offer direct wage employment to people who work in primary and secondary co-operatives as well as in governmental co-operative support institutions (eg ministries, departments, co-operative colleges, etc). Secondly, co-operatives offer selfemployment to members, whose participation in the economic activities that they make possible substantially guarantees a decent income. Thirdly, co-operatives also indirectly employ through the spillover effects of their activities on non-members whose incomegenerating activities are only viable through the transactions they have with, as well as opportunities created by, co-operative ventures.

Of these three, direct wage employment presents the least contribution to employment and income-generation in Africa, yet data from the field shows an increase in the number of people employed over the years. In 1997, an ILO study estimated that the co-operative sector had directly created 158,640 jobs in 15 African countries (Schwettmann, 1997: 7). Our evidence from the field suggests that the sector is actually employing more. For instance, co-operatives and support government institutions are reportedly employing a staggering 77,400 staff in Kenya (Wanyama, 2008); 28,000 in Ethiopia (Lemma, 2008); 9,500 in Egypt (Aal, 2008); 3,130 in Ghana (Tsekpo, 2008); 2,823 in Uganda (Mrema, 2008); and about 800 in Rwanda (Nyamwasa, 2008). Going by the total figure of 121,653 jobs from these six countries, data from another nine countries would definitely surpass the ILO finding of 1997.

To buttress this evidence, Table 2 below provides data on employment effect and the economic performance of some of the prominent co-operatives in the countries under review.

A more detailed analysis by Wanyama and Lemma for Kenya and Ethiopia, respectively, suggest that employment in the sector might even be higher than these official figures. In Kenya, a study of the agricultural sector in 2001 showed that there were only 11,311 permanent employees in the sector (ICA, 2002: 14), but Githunguri Dairy Farmers Co-operative Society alone had 250 employees in that year, increasing to 300 in 2005. Yet this co-operative is just one out of the over 2,000 agricultural co-operatives that are active, with varying direct employment capacities. Among the governmental co-operative support institutions, the Co-operative College had 104 permanent employees, while the Ministry of Co-operative Development and Marketing had slightly over 1,300 staff in 2005. In the financial sector, the Co-operative Bank alone employed over 1,200 while Co-operative Insurance Company had over 600 employees in the same year. Just the top ten SACCOs in terms of annual turnover in 2005 had a total workforce of 1,154 , yet there were over 2,600 active SACCOs spread across the country. These estimates imply that the total number of employees in co-operatives could be more than the above stated estimates (Wanyama, 2008).

Moreover, the direct employment figures presented above do not include the seasonal and casual work that co-operatives create. On the basis of available data from grain marketing co-operatives and coffee farmers' co-operative unions in Ethiopia, Lemma (2008) estimates that over 21,000 people are recruited for casual labour services in co-operatives every year. Nyamwasa (2008) estimates that tea planters' co-operatives alone in Rwanda engage an impressive 4,476 temporary workers on a yearly basis.

The impact of co-operatives on employment creation and income-generation is more discernible in the self-employment realm. A significant proportion of farmers and their households sell their produce to earn an income through their co-operatives. For instance, whereas 924,000 farmers in Kenya earned an income as a result of their membership in agricultural co-operatives in 2004 (Wanyama, 2008), about 4 million farmers in Egypt would have seen their incomes further diminished had they not been members of agricultural marketing co-operatives in 2005 (Aal, 2008). In Ethiopia, about 900,000 people in the agricultural sector generate part or all of their income through their co-operatives (Lemma, 2008).

Even more significant for income-generation is the fact that these co-operatives not only create marketing opportunities for members, but also try to increase their income margins by negotiating for better prices. In Ethiopia, for 
Table 2: The Employment Effect and Performance of Selected Co-operatives

\begin{tabular}{|c|c|c|c|c|c|c|}
\hline Country & Name and type & Members & $\begin{array}{c}\text { Direct } \\
\text { Employees }\end{array}$ & $\begin{array}{l}\text { Economic } \\
\text { Performance }\end{array}$ & Main Act ivity & Other services \\
\hline $\begin{array}{l}\text { Cape } \\
\text { Verde }\end{array}$ & $\begin{array}{l}\text { UNICOOP de } \\
\text { Fogo } \\
\text { (consumers) }\end{array}$ & 404 & 58 & $\begin{array}{l}€ 2.8 \text { million } \\
\text { turnover }\end{array}$ & $\begin{array}{l}\text { Consumer } \\
\text { goods }\end{array}$ & $\begin{array}{l}\text { Loans, house } \\
\text { repair, funeral } \\
\text { assistance }\end{array}$ \\
\hline Egypt & $\begin{array}{l}\text { Agricultural } \\
\text { Production } \\
\text { Co-op Giza }\end{array}$ & 145 & $\begin{array}{r}145 \\
\text { (member- } \\
\text { workers) }\end{array}$ & $\mathrm{n} / \mathrm{a}$ & $\begin{array}{l}\text { Joint } \\
\text { production }\end{array}$ & $\begin{array}{l}\text { skills } \\
\text { development, } \\
\text { transport }\end{array}$ \\
\hline Egypt & $\begin{array}{l}\text { General } \\
\text { Co-operative for } \\
\text { Weaving and } \\
\text { Spinning } \\
\text { Workers }\end{array}$ & 38,950 & 900 & $\begin{array}{l}\text { E£69.2 million } \\
\text { turnover }\end{array}$ & $\begin{array}{l}\text { Consumer } \\
\text { goods }\end{array}$ & \\
\hline Ethiopia & $\begin{array}{l}\text { Oromia Coffee } \\
\text { Farmers' Union } \\
(\mathrm{sec})\end{array}$ & 74,725 & 20 & $\begin{array}{l}\$ 8 \text { million } \\
\text { turnover, } 2691 \\
\text { tons of coffee }\end{array}$ & $\begin{array}{l}\text { Coffee } \\
\text { marketing } \\
\text { and exports }\end{array}$ & $\begin{array}{l}\text { Coffee shops in } \\
\text { Europe and US; } \\
\text { founded a Co-op } \\
\text { Bank }\end{array}$ \\
\hline Ghana & $\begin{array}{l}\text { Kuapa Kokoo Ltd } \\
\text { (cocoa } \\
\text { marketing) }\end{array}$ & 45,000 & 261 & $\begin{array}{l}\text { Sells } 38000 \text { tons } \\
\text { of cocoa per } \\
\text { year }\end{array}$ & $\begin{array}{l}\text { Cocoa } \\
\text { marketing }\end{array}$ & $\begin{array}{l}\text { savings and } \\
\text { credit, } \\
\text { community } \\
\text { development, } \\
\text { chocolate }\end{array}$ \\
\hline Kenya & $\begin{array}{l}\text { Githunguri Dairy } \\
\text { Farmers Co-op }\end{array}$ & 6,000 & 300 & $\begin{array}{l}80000 \text { litres of } \\
\text { milk per day, Ksh } \\
1 \text { billion turnover }\end{array}$ & $\begin{array}{l}\text { Milk } \\
\text { marketing } \\
\text { and } \\
\text { processing }\end{array}$ & $\begin{array}{l}\text { Animal feed; } \\
\text { insemination; } \\
\text { extension; credit }\end{array}$ \\
\hline Niger & $\begin{array}{l}\text { Groupements } \\
\text { Mooriben (cereal } \\
\text { banks) (tert) }\end{array}$ & 19,112 & 450 & $\begin{array}{l}\text { Covers } 37 \% \text { of } \\
\text { food } \\
\text { requirements }\end{array}$ & Grain storage & $\begin{array}{l}\text { Input supply, } \\
\text { credit, } \\
\text { extension, radio }\end{array}$ \\
\hline Nigeria & $\begin{array}{l}\text { CICS Nigerian } \\
\text { Police } \\
\text { Co-operatives } \\
\text { (sec) }\end{array}$ & 110,000 & 120 & & $\begin{array}{l}\text { Credit \& } \\
\text { consumer } \\
\text { items }\end{array}$ & \\
\hline Nigeria & $\begin{array}{l}\text { University } \\
\text { Women's Co-op } \\
\text { Society }\end{array}$ & 250 & 55 & $\mathrm{n} / \mathrm{a}$ & $\begin{array}{l}\text { Consumer } \\
\text { goods }\end{array}$ & Nur sery school \\
\hline Rwanda & $\begin{array}{l}\text { Union des } \\
\text { Banques } \\
\text { Populaires (sec) }\end{array}$ & 398,799 & 600 & $\begin{array}{l}\text { \$44 million } \\
\text { savings, } \$ 36 \\
\text { million loans, } \\
\$ 1.5 \text { million net } \\
\text { profit }\end{array}$ & $\begin{array}{l}\text { Savings and } \\
\text { credit }\end{array}$ & Risk coverage \\
\hline Senegal & $\begin{array}{l}\text { Housing } \\
\text { Co-operative } \\
\text { Mboro }\end{array}$ & 400 & 30 & $\begin{array}{l}\text { CFA } 800 \text { million } \\
\text { invested }\end{array}$ & Construction & Life insurance \\
\hline Tanzania & $\begin{array}{l}\text { Kasimana } \\
\text { Agricultural } \\
\text { Marketing } \\
\text { Co-operative } \\
\text { Society }\end{array}$ & 160 & 6 & TSh 176 million & $\begin{array}{l}\text { Tobacco } \\
\text { marketing }\end{array}$ & $\begin{array}{l}\text { Distribution of } \\
\text { inputs to } \\
\text { members }\end{array}$ \\
\hline Uganda & $\begin{array}{l}\text { Uganda Co-op } \\
\text { Transp ort Union } \\
\text { (UCTU) }\end{array}$ & 44 & 95 & $\$ 3.5$ million & $\begin{array}{l}\text { Joint } \\
\text { transport }\end{array}$ & \\
\hline
\end{tabular}

Source: Develtere et al (2008) 
example, grain producers' co-operatives play an important role in securing better prices for farmers throughout the year. This effort reduces the seasonal price fluctuation and stabilises the local grain markets in favour of co-operators (lbid). Similarly, coffee co-operatives have played a similar role in Ethiopia by penetrating alternative markets that offer better prices in Europe and USA through fair trade (Ibid; Tesfaye, 2005).

Besides agricultural co-operatives, SACCOs are increasingly becoming a major source of productive resources that are invested to create employment opportunities and increase income to the household. These co-operatives are increasingly expanding their ability to mobilise substantial savings from which members can borrow. In Kenya, the turnover of SACCOs almost doubled the combined income of all agricultural co-operatives in 2004. That SACCOs are the prime movers of the co-operative sector is illustrated by the fact that their turnover of Kshs 8.359 billion (US\$ 120 million) in the year under review constituted 62 per cent of the total turnover of all co-operatives in the country. Their financial strength saw them become the majority shareholders in the Co-operative Bank of Kenya, the fourth largest bank in the country, thereby occupying the position that was previously held by agricultural marketing societies (Wanyama, 2008). A similar account obtains in Ghana where the credit unions recorded a turnover of over 425 billion cedi (US\$ 47.2 million) in 2004 (Tsekpo, 2008).

With such resources, SACCOs make loans available to their members for a variety of uses, the most common of which being the creation of employment and income-generation opportunities. For instance in Ghana, a study of the University of Ghana Co-operative Credit Union indicates that members frequently obtain loans to support informal businesses that supplement their wage income. These informal businesses are also known to offer part-time employment to housewives and domestic assistants in the University Staff Village. Indeed an examination of the uses to which loans and withdrawals by members of the co-operative were put listed business as the leading of the nine substantive uses to which members put their funds (Ibid).

This finding resonates with accounts from other countries. At Maseno University SACCO in Kenya, members have obtained loans to invest in businesses and farming, not just to supplement their incomes, but also to create employment for their spouses (Wanyama, 2008). In Rwanda, members of Assetamorwa (Association de l'Esperance des Taxi Motor au $R$ wanda), a co-operative and trade union for motorcycle taxi drivers, get loans from their organisation to buy their own motorcycles to enhance their incomes. They previously paid extortionate daily rental fees to owners of the hired motorcycles (Smith \& Ross, 2006: 16-22). In Ethiopia, SACCOs generate self-employment for about 400,000 people all over the country by extending small loans to micro-entrepreneurs in handicrafts and service sectors (Lemma, 2008). The list of similar examples can be long.

Finally, the spillover effect of the co-operative sector on employment creation and income generation is very diffused and difficult to estimate, but there are some credible indications. It is clear that several categories of people rely on the vibrancy of the co-operative sector for their income by providing inputs to co-operative enterprises or selling products from co-operatives at the marketplace. For instance in Kenya, a substantial number of entrepreneurs who are not members of co-operatives derive their income from trading in office stationery used in co-operatives; packaging paper used by dairy co-operatives to pack products; machinery for primary processing of agricultural produce like coffee and milk; and farm inputs stocked in co-operative stores. Then there are people who earn some income by marketing products from co-operatives. Dairy co-operatives, for example, produce various products like fresh milk, ghee, butter and yoghurt while other agricultural co-operatives market coffee, fish, pyrethrum, etc that are usually handled by nonmember entrepreneurs at some point in the marketing chain. It is for this reason that it is estimated that over three million people in Kenya derive a significant part of their income from the activities and services of co-operatives. This represents over ten per cent of the current estimates of the country's total population (Wanyama, 2008).

Moreover, the financial services that co-operatives avail in the countryside are equally significant. The SACCO movement is quickly spreading from its traditional urban and wage employment sectors into the rural and informal sectors, thereby widening the scope of financial service provision. In Kenya, for instance, some of the urban- and employer-based SACCOs like Mwalimu and Harambee have opened branches 
outside Nairobi, with Front Office Services (including withdrawable savings deposit products and instant cash advances on salaries) that facilitate cash flow in areas that commercial banks have traditionally shunned (Ibid). Such services have benefited not just the members, but also local businesses and people.

By creating employment opportunities, generating income and facilitating financial flow for the members and non-members, co-operatives make available to the individual and household financial resources that are utilised to participate in activities through which a living is earned.

\section{Co-operative Investment in Human Capital}

As much as ignorance or illiteracy and poor health tend to be manifestations of poverty, they are also causes of the same. Consequently, efforts towards improving on the provision of educational and health services are fundamental for poverty reduction. Co-operatives have made a contribution in this regard in three different ways. First, members of co-operative societies use the income that these societies make possible to educate their children. Loans from SACCOs have particularly been instrumental in this regard. In Kenya, the main type of back office loan offered by most SACCOs (at interest rates of 1 to 1.5 per cent on monthly reducing balances for a 12-month period) is for paying school fees (Evans, 2002: 22-23). Similar reports obtain from Ghana, Nigeria, Cape Verde and Uganda. An example from Uganda is particularly illustrative. A study of Jinja Teachers Savings and Credit Society showed that three of the members who borrowed from the co-operative to pay their children's school fees have seen their three respective children graduate in medicine, engineering and finance. The children are now employed and provide financial assistance to their relatives and parents (Mrema, 2008).

Secondly, co-operatives are also serving as educational centres for members. Some members shade off some degree of ignorance on economic opportunities in their milieu through co-operative educational programmes. The case of Rooibos Tea Co-operative Society in South Africa is illustrative. In 2000 , fourteen small rooibos tea farmers in the dry, mountainous region north of Cape Town, who had been introduced to organic tea farming by a representative of an environmental NGO, decided to form the co-operative with a view to establishing a facility to process each member's tea before it could be delivered to a marketing company. After some time, there was unhappiness with the price the company paid for the tea. The organisational dynamics of the co-operative soon enabled members to learn that they could get a much better price by marketing their tea through a local fair trade agent who was promoting the marketing of organic agricultural produce rather than the company.

The better price that the farmers received on marketing their tea through the said agent served as an eye opener to the economic potential of rooibos tea farming that they decided to lease a centrally located facility to increase production. So successful was the venture that the co-operative started realising a substantial surplus. The 100 South African rands (US\$ 15.6) entrance fees contributed by the fourteen founding members in 2001 had raised an initial capital of only 1,400 rands (US\$222.2). At the end of 2004 the co-operative membership had increased to 36 with a turnover of 1.25 million rands (US\$ 198,412.7) and assets valued at 896,708 rands (US\$142,334.6), including a truck to deliver the tea, a welding machine and a tractor used in the production of tea. Of significance to the educational needs of the members is that the co-operative had committed thirty per cent of its annual profit to the training of those members who, in the opinion of the board, had been most disadvantaged for their race and/or gender to undertake sustainable economic activities. The training and development programmes in this regard included various topics ranging from financial management to global climatic changes that affect tea production (Theron, 2008).

Similarly, the Menshat Kasseb agricultural co-operative society in Giza region of Egypt not only supports members to market their produce, but also provides non-economic services like training female members in home economics and health care. It also organises members rights and responsibilities awareness-raising workshops to enlighten members on the virtues of co-operation. Besides such training initiatives by societies, all central co-operative unions in Egypt regularly organise training courses for the staff of affiliated societies to enhance managerial capacity (Aal, 2008).

Kenyan co-operatives, with the support of donors, have undertaken similar initiatives to train their members. The Swedish Co-operative Centre (SCC) funds co-operative members' 
education through specialised programmes. For example, it has funded a project known as Community Empowerment and Economic Development through Co-operatives (CEEDCO) to educate members of Githunguri Dairy Farmers Co-operative Society on the value of co-operatives in development and their role as members of these enterprises (Wanyama, 2008). All these efforts have significantly contributed to the reduction of ignorance among co-operators and, therefore, improved on human capital.

Thirdly, co-operatives have also invested in human capital by contributing to the improvement of the health of their members. SACCOs are, for example, known to give loans to members to enable them pay medical bills or seek expensive medication in several countries including Ghana, Kenya and Uganda. In Rwanda, members obtain loans from their credit co-operatives to pay annual health insurance premiums in their mutual health schemes (Nyamwasa, 2008). Other co-operatives in the same country have set up health and insurance funds from their savings schemes, one example being Assetamorwa (Smith and Ross, 2006: 22). In Egypt, the spinning and weaving workers' co-operative society at El-Mehala Al-Kubra gives financial support towards meeting the medical expenses of members and their families (Aal, 2008).

It is also significant to note that co-operatives in some countries participate in health promotion campaigns to ensure the good health of their members. This is the case in Ethiopia where five co-operative unions in Oromia region have established HIVIAIDS clubs for raising awareness about the disease and enhancing the use of prevention and control measures to reduce its spread among members. This effort has created a forum for exchanging experiences with people living with HIVIAIDS as well as disseminating information on the disease through the distribution of translated manuals provided by the ILO (Lemma, 2008). Similarly, Assetamorwa in Rwanda, pursuant to one of its objectives of fighting HIVIAIDS amongst public transport operators, has set up a club to combat the spread of the disease through awareness creation (Smith and Ross, 2006: 21).

These contributions to the educational and health demands of the members have seen co-operatives credited for reducing ignorance and disease in societies where they operate, thereby developing human capital in Africa.

\section{Social Protection}

By social protection we refer to societal security mechanisms for responding to unexpected socio-economic scarcity and risks that people encounter in their livelihoods. Traditional African society relied on mutual aid to secure every individual from calamities that were beyond his/ her capacity to handle. In its simplest form, mutual aid found expression in interfamilial and neighbourly help in bringing back strayed cattle; tending the crop of someone fallen ill; chasing away marauding wildlife; and helping family, kin and villager to ease the burden of death by meeting funeral expenses, among others (Bouman, 1995: 118). Though some of these mutual support habits have survived the onslaught of modernity, they are clearly inadequate to withstand the shocks that visit livelihoods today.

On the other hand, the small tax base, the prevalence of the informal economy and the institutional weaknesses of the African state hinders the establishment or extension of formal, public social protection systems to cater for all in society; thereby exposing the poor to the vagaries of unexpected calamities. In the circumstances, it is only the minority wealthy people who benefit from social protection systems provided by private insurance companies. It is against this background that cooperatives are attempting to act as networks for securing the individual against unexpected calamities that derail livelihoods.

In the first place, both the back office and front office activities of SACCOs secure members from unexpected financial expenses. With regard to back office activities, SACCOs offer emergency loans to their members for a term of twelve months to solve unanticipated problems. This acts as a fall-back for members to quickly respond to unexpected socioeconomic problems like sickness, an accident, crop failure and food shortages, among others. Though most co-operatives usually have limited funds for such loans, resulting in the inability of SACCOs to effectively respond to increasing demands for emergency loans as is the case at Maseno University SACCO in Kenya (Wanyama, 2008), many SACCOs have designed regulations to ensure that only the very deserving cases benefit from these loans to guarantee the availability of some funds at any given time.

In the front office service activities, SACCOs have devised innovative banking services and 
cash salary advances that are popularly referred to as "instant loans". Under varying conditions, SACCOs approve and pay these advances in less than one day (Evans, 2002: 18). Unlike emergency loans, these advances are payable in a shorter period of time, usually not more than six months, and the ceiling on borrowing depends on the individual's ability to repay within the said period of time. The fact that these loans can be accessed within a very short time to respond to unexpected emergencies has seen them become more popular than emergency loans, though their repayment terms are shorter and interest rates are higher. In Kenya, the popularity of these loans has, however, outstripped the available funds in most SACCOs (lbid).

Secondly, in response to the rising cost of funerals, some co-operatives, particularly SACCOs, have introduced benevolent funds to cater for burial expenses of members and their immediate family members in case of death. Co-operative members make regular contributions to such funds, but only draw from when they are bereaved. The schemes define the relatives on whose death the member could get assistance to meet the burial expenses as well as the respective amount of money he/she would be entitled to. In the event of a member's death, his/her immediate family gets assistance from the fund to meet burial expenses. It should, however, be emphasised here that in some instances, it is not the cost of funerals that has led co-operatives to set up these funds, but the exclusion that their members encounter. For instance, the Jinja Teachers Savings and Credit Co-operative Society in Uganda, most of whose members were seriously affected by the killer HIVIAIDS disease, had been excluded from the burial contribution scheme within the District Council by virtue of their infection. The co-operative responded by establishing its own benevolent fund to cover burial expenses for any society member who died or who lost a family member (Mrema, 2008).

Thirdly, co-operatives in some countries have established social funds from their annual profits to provide for communal needs. For instance, in Ethiopia, all co-operatives are required to allocate $1-5 \%$ of their profit to a social fund that is used to provide basic social services and develop communal infrastructure such as roads, schools, health clinics or watering points. For example, Yirga Chefe Coffee Farmers Co-operative Union gives financial support to 21 students in institutions of higher learning in the country annual. It also provides school uniforms and other educational materials to 250 orphans annually. In the same spirit, Dibandiba Primary Co-operative Society made a contribution of 7,500 Ethiopian Birr towards the construction of a watering point and the purchase of chairs at a local primary school in 2005 (Lemma, 2008).

Fourth, co-operatives are also making provision for food security in some countries. The Mooriben federation, formed in 1988 in western Niger, serves as an example. It started with the broader objective of fighting ignorance and poverty ("mooriben" in Djerma-Sonrai means "poverty has ended"), but has since initiated a multiplicity of activities. Mooriben's package of services includes training; grain banks; farmers' shops; credit lines; and community radio stations. Each element of this package meets a specific need, but the synergy between all the elements helps to improve farmers' living conditions. In particular during periods of food crisis, the neighbourhood services made possible by the grain banks and provision of farm inputs to members have been instrumental in ensuring food security.

Indeed, the grain banks and farmers' shops have substantially changed farming practices. Before, farmers consumed or sold all of their harvest and accrued debts to traders in lieu of the next harvest. This dependence on traders has declined sharply since the creation of the grain banks. The existence of Mooriben farmers' shops has improved farmers' access to quality seeds and other farm inputs. Farmers are able to make informed choices between the various inputs in order to improve productivity. This partly explains why Mooriben is one of the three civil society organisations to which the Ministry of Agriculture in Niger has quite often turned for the distribution of seeds in order to manage food crises. In terms of food security, the grain banks made it possible to cover the food needs of about 24,941 people (about $37 \%$ of the needy population) during the critical months of famine in 2005 (Sani, 2008).

Fifth, it is significant that co-operatives also safeguard the jobs of their members, particularly in countries where the trade union movement provides the foundation for co-operatives. A case in point is Rwanda where co-operatives pool their efforts to provide workers in the informal sector with greater bargaining power vis-à-vis the 
administration with regard to taxes, workplace conditions and the relaxation of certain repressive regulations that target the informal economy (Nyamwasa, 2008).

For instance, before Assetamorwa was formed, the jobs of motorcycle taxi operators were threatened by a host of problems, including the Kigali City Council regulations like the wearing of a helmet by both the driver and the passenger as well as possession of an up-to-date driving license, both of which required money that most operators did not have. To overcome these problems, the operators formed this co-operative cum trade union with a view to collectively secure their jobs by combating unemployment; improving the image of public transport operators; fighting ignorance; strengthening the unity of, and promoting reconciliation among, public transport operators; teaching public transport operators the Highway Code; establishing insurance for public transport operators; fighting for the security of public transport operators and their passengers; and mobilising savings to enable operators acquire expensive requirements for their jobs like helmets and driving licenses. The good progress so far recorded on all these issues has substantially helped to secure the jobs of these operators (Smith and Ross, 2006: 18-23).

In these various small ways, co-operatives are protecting their members and the wider community against unexpected calamities that tend to disrupt livelihoods. We note that these organisations sometimes re-enforce traditional mutual support habits that are common to most African communities by simply formalising them. As Enete (2008) rightly remarks, social security systems in co-operatives tend to be spelt out in the constitution and by-laws, whereas in typical African communities, the system was conventional and ad hoc in character. It is, therefore, significant that cooperatives are formalising social security in a region where this mechanism is largely underdeveloped and do expose the poor to extensive vulnerability.

\section{Conclusion}

The purpose of this discussion has been to demonstrate the contribution of co-operatives to poverty reduction in Africa since the liberalisation of the sector in the mid 1990s. From a rural livelihoods perspective, it is evident that co-operatives have significantly contributed to the mobilisation and distribution of financial capital by creating employment and incomegenerating opportunities for both their members and non-members alike. In the midst of lingering patterns of exclusion and inequality that tend to be based on ethnic, class or professional biases, co-operatives are increasingly witnessing the participation of people from these diversities in the same ventures. Accordingly, these organisations are utilising their relatively less excluding features like open and voluntary membership and democratic leadership to reduce exclusion in society by enabling those willing to join an opportunity to generate an income. The income so-generated is used not just to meet household consumption needs, but also to enhance income-generating capacities of people by investing in educational and health requirements of individuals and households. Furthermore, co-operatives contribute to human capital by creating a forum for education and training for their members in a bid to reduce ignorance. They also enable their members to mobilise funds for taking care of their health needs. In the absence of formal social security systems, co-operatives are increasingly creating solidarity mechanisms to re-enforce the informal traditional mutual aid systems by opening opportunities to set up schemes to cater for unexpected expenses related to illness, social welfare, death and other unexpected socioeconomic problems like drought and crop failure. These modest contributions are slowly eroding the previous mistrust that people had in African co-operatives to pave way for their acceptance as potential mechanisms for mediating access to productive resources that can be utilised to participate in livelihood activities. It is in this regard that co-operatives are increasingly contributing to poverty reduction in Africa.

\section{Fredrick O Wanyama holds a PhD in Political Science from Maseno University, Kenya where he is a Senior Lecturer and Director of the School of Development and Strategic Studies. Specialising in local organisations and politics in the African development process, he has contributed many chapters and articles to academic books and refereed journals. He is a recipient of fellowships from distinguished bodies like CODESRIA, DAAD, the Five}


College African Scholars Program, Amherst, Massachusetts, USA and HIVA at the Katholieke University of Leuven, Belgium. Patrick Develtere holds a PhD from the Katholieke University of Leuven, Belgium. He has been studying co-operatives and other civil society organisations in Europe, Africa, Asia and Latin America for more than $\mathbf{2 0}$ years. He is the Director of the Higher Institute for Labour Studies (HIVA) at the Katholieke University of Leuven. He has published several books and articles on co-operatives, the social economy and development. Ignace Pollet is a senior researcher of the Higher Institute for Labour Studies at the Katholieke University of Leuven, Belgium. As an organisation specialist, he has a track record in research on different types of popular organisations as well as enterprises in both Belgium and developing countries. He has published many articles on this subject.

\section{Bibliography}

Aal, Mohamed HA(2008) “The Egyptian Cooperative Movement: Between State and Market”, in P Develtere, I Pollet \& F Wanyama (eds), Cooperating out of Poverty: The Renaissance of the African Cooperative Movement, Geneva: ILO \& Washington DC: The World Bank Institute, Geneva/Washington DC, pp241-263.

Birchall, J (2004) Co-operatives and the Millennium Development Goals, Geneva: ILO.

Birchall, J (2003) Rediscovering the Co-operative Advantage: Poverty Reduction Through Self-help, Geneva: ILO.

Bouman, F J A (1995) "ROSCA: On the Origin of the Species," Savings and Development, Vol 19, No 2, pp117-148.

Carswell, G (1997) “Agricultural Intensification and Rural Sustainable Livelihoods: A “Think Piece,” IDS Working Paper No 64, Brighton: Institute of Development Studies, University of Sussex.

Chambers, R \& Conway R (1992) "Sustainable Rural Livelihoods: Practical Concepts for the $21^{\text {st }}$ century," IDS Discussion Paper No 296, Brighton: Institute of Development Studies, University of Sussex.

Davies, S \& Hossain, N (1997) “Livelihood Adaptation, Public Action and Civil Society: AReview of the Literature," IDS Working Paper No 57, Brighton: Institute of Development Studies, University of Sussex.

Develtere, P (2008) "Cooperative Development in Africa up to the 1990s", in Develtere, et al (eds) Cooperating out of Poverty, op. cit., pp1-37.

Develtere, $\mathrm{P}$ and Pollet, I (2008) "Renaissance of African Cooperatives in the $21^{\text {st }}$ Century: Lessons from the Field", in Develtere et al (eds) op cit, pp38-90.

Ellis, F (2000) Rural Livelihoods and Diversity in Developing Countries, Oxford: Oxford University Press.

Enete, A (2008) "Political and Genuine Cooperatives in Enugu State-Nigeria", in Develtere, et al (eds) Cooperating out of Poverty, op cit, pp208-224.

Evans A C (2002) The Unpaved Road Ahead: HIV/AIDS \& Microfinance: An Exploration of Kenya Credit Unions (SACCOs), Research Monograph Series No 21, World Council of Credit Unions, Madison, Wisconsin.

Hussi, P, Murphy, J, Lindberg, O and Brenneman, L (1993) The Development of Co-operatives and Other Rural Organizations: The Role of the World Bank, Washington, DC: The World Bank.

Hussein, K and Nelson, J (1998) "Sustainable Livelihoods and Livelihood Diversification," IDS Working Paper No 69, Brighton: Institute of Development Studies, University of Sussex.

International Cooperative Alliance (ICA) (1995) "Statement on the Cooperative Identity", in Review of International Cooperation, Vol 88, No 3.

ICA (1996) Restructuring of the Cooperative Movement in Uganda, ICA Regional Office for East, Central \& Southern Africa, Kampala.

International Labour Office (ILO) (1960) Co-operative Management and Administration, Geneva: International Labor organization.

International Labour Organization (2002) Recommendation 193 of the ILO On Promotion of Co-operatives, ILO, Geneva.

ILO/ICA (2003) The role of cooperatives in designing and implementing poverty reduction strategies, Regional Workshop Report, Dar es Salaam.

Lemma, T (2008) "Growth without Structures: The Cooperative Movement in Ethiopia”, in Develtere, et al (eds) Cooperating out of Poverty, op cit, pp128-152.

Mendonca, J G (2008) "Surviving on the Islands: Cooperatives in Cape Verde", in Develtere, et al (eds) Cooperating out of Poverty, op cit, pp264-280.

Mrema, H A(2008) “Uganda: Starting all over Again”, in Develtere, et al (eds) Cooperating out of Poverty, op cit, pp153-174.

Nyamwasa, J D (2008) “Jump-starting the Rwandan Cooperative Movement”, in Develtere, et al (eds) Cooperating out of Poverty, op cit, pp281-305.

Porvali, H (ed) (1993) The Development of Co-operatives, Agriculture and Rural Development Series No 8 , Washington, DC: The World Bank.

Sani, S M (2008) "Bad Memories, Good Prospects: Cooperatives in Niger", in Develtere et al (eds) Cooperating out of Poverty, op cit, pp225-240. 
Schwettmann J (1997) "Cooperatives and Employment in Africa”, Discussion paper, International Labour Office, Geneva.

Scoones, I (1998) "Sustainable Rural Livelihoods: A Framework for Analysis," IDS Working Paper No 72, Brighton: Institute of Development Studies, University of Sussex.

Sen, A (1999) Development as Freedom, New York: Alfred A. Knopf Inc.

Smith, S \& Ross, C (2006) How the SYNDICOOP Approach has Worked in East Africa, Geneva: ILO, ICA and ICFTU.

Spence, W R (2005) "Power Structures and Capacity Aspects of Macro-Poverty Analysis", Development Policy Review, Vol 23, No 3. pp351-367.

Tesfaye A (2005) Revitalizing Market-Oriented Agricultural Cooperatives in Ethiopia, Addis Ababa: ACDI-VOCA.

Theron, J (2008) "Cooperatives in South Africa: AMovement (re-)emerging", in Develtere et al (eds), Cooperating out of Poverty, op cit, pp306-329.

Tsekpo, AK (2008) “The Cooperative Sector in Ghana: Small and Big Business", in Develtere et al, Cooperating out of Poverty, op cit, pp175-207.

Wanyama, F O (2008) "The Qualitative and Quantitative Growth of the Cooperative Movement in Kenya", in Develtere, et al (eds), Cooperating out of Poverty, op cit, pp91-127.

\section{Notes}

1 The purpose of the said study was to obtain qualitative insights into the strengths and weaknesses of the co-operative movement in the countries with a view to assessing the real and potential impact of co-operatives on reduction of poverty through creation of employment; generation of economic activities; enhancement of social protection; and improvement of the voice and representation of vulnerable groups in society. The researchers, one in each of the eleven countries, first of all used qualitative rapid assessment methodology to collect data at the national level using semi-structured interviews with key informants in the cooperative sector. This was followed by in-depth interviews with leaders and members in selected co-operative societies at the local level with a view to generating case studies to illuminate on the findings from the national level. The eleven countries are Ethiopia, Egypt, Kenya, Uganda, Rwanda, South Africa, Nigeria, Ghana, Niger, Senegal and Cape Verde. The overall findings of this study (which was carried out in 2005) have been published in Co-operating out of Poverty: the Renaissance of the African Cooperative Movement, edited by Patrick Develtere, Ignace Pollet and Fredrick Wanyama, Geneva: International Labour Office \& Washington DC: The World Bank Institute, 2008.

2 By people of limited means we refer to those who want to start an enterprise but do not have accumulated capital or alternative credit facilities to do so. 